\title{
Determination of the adaptability and stability of soybean cultivars in different locations and at different sowing times in Paraná state using the AMMI and Eberhart and Russel methods
}

\section{Determinação da adaptabilidade e estabilidade de cultivares de soja em diferentes locais e épocas de semeadura no estado do Paraná usando os métodos AMMI e Eberhart e Russel}

\author{
Daniel Augusto Silveira ${ }^{1}$; Luiz Fernando Pricinotto ${ }^{2}$; Maicon Nardino ${ }^{3}$; \\ Carlos André Bahry ${ }^{4 *}$; Cássio Egídio Cavenaghi Prete ${ }^{5}$ : Luan $\mathrm{Cruz}^{6}$
}

\begin{abstract}
This study aimed to evaluate the adaptability and phenotypic stability of 10 soybean genotypes in 12 environments in Paraná state by using the additive main effects and multiplicative interaction analysis (AMMI) and Eberhart and Russell models. The assays were conducted in a randomized complete block design with three replicates, in the 2010/2011 season in four locations in Paraná state (Assaí, São Pedro do Ivaí, Cornélio Procópio, and Marilândia do Sul), and with three sowing dates (15/-20/10/10; 29/1003/11/10; 15/-20/11/10). The cultivars tested with Roundup Ready ${ }^{\circledR}$ technology included SYN 1049, SYN 1152, SYN 1059, SYN 3358, SYN 1163, SYN 1157, V-MAX, FT Campo Mourão, BMX Potência, and SYN 9070. The yield character was analyzed. Data were submitted to analysis of variance and the adaptability and stability were then analyzed. The results of the AMMI and Eberhart and Russell models were somewhat consistent for the stability parameter only. The AMMI analysis was able to capture $66 \%$ of the variance associated with residue no additives, of which $43.18 \%$ was retained in the first principal component of interaction and $23.58 \%$, in the second component. This is sufficient to explain the genotype $\times$ environment interaction. The SYN 1059, SYN 1163, and VMAX genotypes are distinguished by their considerably higher yield and productive adaptation. In the AMMI analysis, the cultivar SYN 1163 showed commercial promise among the other cultivars for high grain yield performance, adaptation, and response predictability.
\end{abstract}

Key words: Biometric models. Predictability. Grain yield. Different environments.

\section{Resumo}

O objetivo do trabalho foi estudar a adaptabilidade e a estabilidade fenotípica de dez genótipos de soja em doze ambientes no Paraná com o uso dos modelos AMMI (Additive Main Effects and Multiplicative Interaction Analysis) e Eberhart e Russel. Os ensaios foram conduzidos em blocos completos casualizados com três repetições na safra 2010/2011 em quatro locais no Estado do Paraná (Assaí, São Pedro do Ivaí, Cornélio Procópio e Marilândia do Sul) e em três épocas de semeadura (15/10/10

\footnotetext{
${ }^{1}$ Pesquisador, Syngenta Proteção de Cultivos Ltda, SYNGENTA, Londrina, PR, Brasil. E-mail: daniel.silveira@syngenta.com

2 Eng $^{\circ}$ Agr $^{\circ}$, Secretaria de Estado da Agricultura e do Abastecimento/Departamento de Desenvolvimento Agropecuário, SEAB/ DEAGRO, Cianorte, PR, Brasil. E-mail: 1fpricinotto@hotmail.com

3 Prof., Universidade Federal de Santa Maria, UFSM, Frederico Westphalen, RS, Brasil. E-mail: nardinomn@gmail.com

${ }^{4}$ Prof., Universidade Tecnológica Federal do Paraná, UTFPR, Dois Vizinhos, PR, Brasil. E-mail: carlosbahry@utfpr.edu.br

5 Prof. Dr., Universidade Estadual de Londrina, UEL, Londrina, PR, Brasil. E-mail: cassio@uel.br

${ }^{6}$ Discente de Mestrado em Agronomia, UEL, Londrina, PR, Brasil. E-mail: agroluan@gmail.com

* Author for correspondence
} 
$-20 / 10 / 10 ; 29 / 10 / 10-03 / 11 / 10 ; 15 / 11 / 10-20 / 11 / 10)$. As cultivares testadas, todas com a tecnologia RR, foram: SYN 1049; SYN 1152; SYN 1059; SYN 3358; SYN 1163; SYN 1157; V-MAX; FT Campo Mourão; BMX Potência; e, SYN 9070. O caráter analisado foi rendimento de grãos. Os dados foram submetidos à análise de variância. Posteriormente realizou-se a análise de adaptabilidade e estabilidade. Os modelos AMMI e Eberhart e Russel foram parcialmente concordantes apenas para parâmetro de estabilidade. A análise AMMI foi capaz de capturar $66 \%$ da variação associada aos resíduos não aditivos, os quais $43,18 \%$ estavam retidos no primeiro componente principal de interação e $23,58 \%$ no segundo componente os quais são suficientes para explicar a interação G×E. Os genótipos SYN 1059, SYN 1163 e V-MAX destacam-se pela produtividade consideravelmente superior e ampla adaptação produtiva. A cultivar SYN 1163, na análise AMMI, mostra-se promissora entre as demais cultivares lançadas comercialmente pelo alto desempenho de rendimento de grãos, adaptação e previsibilidade de resposta. Palavras-chave: Modelos biométricos. Previsibilidade. Rendimento de grãos. Diferentes ambientes.

\section{Introduction}

Soybean crops occupy vast areas, which ensures differential responses of genotypes to environmental variations. Thus, the interaction between genotypes and environments is relevant for improving plant breeding. Understanding this interaction is essential for breeding programs in order to reduce the amplitude of the characteristics related to productivity due to the environmental variation (DUARTE; VENCOVSKY, 1999). The stability and specific adaptations of genotypes to different environments may indicate the difference between a good and an excellent cultivar (BRANQUINHO et al., 2014; GAUCH; ZOBEL, 1996).

To enable the cultivation of late-season corn in Paraná, soy is sown early (MEOTTI et al., 2012). Sowing time is directly related to the success of the crop due to environmental changes such variation in water levels, temperature, and solar radiation available to plants (BARBOSA et al., 2013; SUBEDI et al., 2007). Delayed sowing and/or the timing of the late season may cause significant losses of $30-70 \%$ compared with the recommended sowing period (BRACCINI et al., 2004; RODRIGUES et al., 2008; STÜLP et al., 2009). This led to the adoption of sowing dates that are associated with climatic conditions similar to those required by the plants, which is extremely important for good productive performance of crops (PEIXOTO et al., 2000; RIBEIRO et al., 2000).

When considering the magnitude of the environment's influence on genotype expression, analysis of the genotype $\times$ environment $(\mathrm{G} \times \mathrm{E})$ interaction is critical for evaluating cultivars in different environments (MEOTTI et al., 2012). When the $\mathrm{G} \times$ E interaction reveals significant effects, the behavior of genotypes under different growing conditions varies. Cruz and Carneiro (2003) have suggested that the nature of the interaction can be simple, given the variability between the genotypes is contrasting and complex as the characteristics of genotypes are superior under certain conditions and do not express superiority in other environmental situations. Evaluation of the $\mathrm{G} \times \mathrm{E}$ interaction becomes very important in crop breeding because when it exists, it is possible that the best genotype in one environment is not the best in another. This influences the selection gain and hinders the recommendation of cultivars with wide adaptability. Given the importance of this interaction, it is the breeder's discretion to assess its magnitude and significance, quantify its effects on breeding techniques and technology dissemination strategies, and provide subsidies that enable procedures to be adopted that minimize the effects and/or their exploitation (CRUZ et al., 2012).

Several theories have been proposed to evaluate the adaptability and stability of cultivars. The most commonly used methods are based on the analysis of variance, analysis of regression, bisegmented regression analysis, non-parametric methods of analysis, visual analysis, multivariate analysis, and analysis of key factors and their main components (CARVALHO et al., 2014; MIRANDA et al., 
2008). Among these methods are those based on regression, including the additive main effects and multiplicative interaction (AMMI) analysis models for $\mathrm{G} \times \mathrm{E}$ and GGE (genotype and genotype $\times$ environment interactions) with the aid of biplot analyses, based on their efficiency (CAMARGOBUITRAGO et al., 2011; PACHECO et al., 2009).

The AMMI and GGE biplot methods are efficient at analyzing the adaptability and stability of cultivars, when assessed at different locations and times of sowing, as they facilitate the interpretation of the interaction in more than one dimension (DUARTE; VENCOVSKY, 1999; MEOTTI et al., 2012; OLIVEIRA et al., 2003). Furthermore, the AMMI and GGE analysis enables the graphical representation of genotypes and environments in a multivariate scattergram (biplot). These diagrams provide information on the stability and phenotypic adaptability, and permit the agronomic zoning and choice of specific environments for the evaluation and selection of cultivars, as they have been used in studies of this nature in soybean (MEOTTI et al., 2012; STÜLP et al., 2009; YOKOMIZO et al., 2013) and in other cultures (MIRANDA et al., 2008; SCHMILDT et al., 2011; SUBEDI et al., 2007).

Therefore, this study aimed to investigate the adaptability and phenotypic stability of 10 soybean genotypes in 12 environments in Paraná using the AMMI and Eberhart and Russell models.

\section{Material and Methods}

The tests were conducted in the 2010/2011 season in four different locations in the state of Paraná (Table 1). The tested cultivars, all with Roudup Ready ${ }^{\circledR}$ technology, used in the adaptability and stability tests, were: SYN 1049 (1), SYN 1152 (2), SYN 1059 (3), SYN 3358 (4), SYN 1163 (5), SYN 1157 (6), V-MAX (7), FT Campo Mourão (8), BMX Potency (9), and SYN 9070 (10).

Table 1. List of locations, altitudes, and sowing seasons of 10 soybean cultivars, obtained during the 2010/2011 harvest in Paraná.

\begin{tabular}{|c|c|c|c|c|c|}
\hline \multirow{3}{*}{ Location } & \multirow{3}{*}{ Municipality } & \multirow{3}{*}{ Altitude (m) } & \multicolumn{3}{|c|}{ Sowing season } \\
\hline & & & Season 1 & Season 2 & Season 3 \\
\hline & & & $15-20$ Oct & 29 Oct-03 Nov & $15-20 \mathrm{Nov}$ \\
\hline L1 & Assaí & 635 & 15 Oct & $03 \mathrm{Nov}$ & 17 Nov \\
\hline L2 & São Pedro do Ivaí & 450 & 19 Oct & 29 Oct & 19 Nov \\
\hline L3 & Cornélio Procópio & 650 & 20 Oct & 29 Oct & $17 \mathrm{Nov}$ \\
\hline L4 & Marilândia do Sul & 700 & 15 Oct & $03 \mathrm{Nov}$ & $17 \mathrm{Nov}$ \\
\hline
\end{tabular}

The testing sites had similar physicochemical characteristics to minimize the effect of the terrain on the performance of genotypes, and were considered to be areas of high fertility based on chemical analyses. The soil of the four sites is characterized as red latosol. Basic fertilization consisted of the application of approximately $300 \mathrm{~kg} \mathrm{ha}^{-1}$ of the NPK 02-20-20 formulation in all areas, given their similarities.

Seed treatment was standardized across all environments and consisted of $200 \mathrm{~mL}$ Cruizer +
Maxim for $100 \mathrm{~kg}^{-1}$ seeds for each product. Aerial management was carried out to control pests by applying Curyom (300 mL ha-1), for soybean caterpillar control, and Engeo Full $\left(200 \mathrm{ml} \mathrm{h}^{-1}\right)$ for bug control. The fungicide Priori Extra was applied at a dose of $300 \mathrm{~mL} \mathrm{ha}^{-1}$ to control fungi.

The experimental design consisted of complete blocks randomized with three replications. Each experimental unit was 20-m long and 10-m wide, with an area of $200 \mathrm{~m}^{2}$. Across all environments, the seed rate was 300,000 ha $^{-1}$ plants, with $0.45-\mathrm{m}$ row 
spacing. The character analyzed was grain yield obtained by harvesting $100 \mathrm{~m}^{2}$ of experimental units and extrapolated to $\mathrm{kg} \mathrm{ha}^{-1}$ after moisture correction to $12 \%$.

Data were submitted to analysis of variance individually to verify the homogeneity of variance. After the joint analysis of all local and sowing times was carried out and the $\mathrm{G} \times \mathrm{E}$ interaction was verified, we proceeded to analyze adaptability and stability using the methods described by Eberhart and Russell (1966) and AMMI. To determine the number of main axes to be retained to explain and graphically represent the standard relation to the $\mathrm{G} \times \mathrm{E}$ interaction, the criteria employed by Gauch and Zobel (1996) were adopted. The $\mathrm{F}_{\text {Gollob }}$ significance test was used as an end point that determines the selection of the model in the family of the AMMI models for successive terms of interaction. It also meets other terms not retained on the selected template in complementary portions of $\mathrm{SG}_{\mathrm{G} \times \mathrm{E}}$, according to the Cornelius F test (CORNELIUS et al., 1992; PIEPHO, 1995).

The computer program GENES was used for all statistical analyses (CRUZ, 2013). Adaptability and stability were analyzed via AMMI by GLM and
IML procedures of the computer application SAS (SAS Institute, Cary, NC, USA), described in detail by Duarte and Vencovsky (1999).

\section{Results and Discussion}

Analysis of variance revealed significant effects for all sources of variation (growth environment, cultivar, and $\mathrm{G} \times \mathrm{E}$ interaction) for the character grain yield (Table 2). The interaction between genotype and environment indicates that the genotypes do not have to be a constant for all evaluation environments; in this way, it is important to determine the $\mathrm{G} \times \mathrm{E}$ interaction. Most quantitative traits, such as productivity, are of polygenic nature and are influenced by the environment where the $\mathrm{G} \times \mathrm{E}$ interaction exerts great influence on the expression of quantitative traits (SCHMILDT et al., 2011). According to Barros et al. (2010a), confirmed interactions are problematic for breeding programs for both the selection phase and for the recommendation of cultivars. However, in order to mitigate the effects of the interaction, the use of cultivars with wide adaptability and good stability is appropriate.

Table 2. Analysis of variation in soybean yield, in $\mathrm{kg} \mathrm{ha}^{-1}$, involving 10 genotypes of soybean, 12 environments, and two repetitions.

\begin{tabular}{lcc}
\hline Variation Factor & GL & Mean Square \\
\hline Block/Environment & 12 & 57354.15 \\
Environments (AMB) & 11 & $2641780.95^{* *}$ \\
Cultivar (CULT) & 9 & $761579.02^{* *}$ \\
CULT $\times$ ENV & 99 & $259968.25^{* *}$ \\
Residual & 108 & 99077.48 \\
Total & 239 & \\
CV $(\%)$ & & 8.25 \\
$\mathrm{R}^{2}$ & & 0.85 \\
General average & & 3811.82 \\
\hline
\end{tabular}

** Significant at $1 \%$ of error probability by the $\mathrm{F}$ test.

${ }^{\text {ns }}$ Not significant by the F test. 
Regarding the adaptability analysis assessed by the $\beta 1$ component through the Eberhart and Russell model, the cultivar SYN 9070 was highly responsive to environmental improvements, as well as all other cultivars with wide adaptability (Table 3). It was also considered to be highly responsive to environmental improvements, i.e., farming can be adapted to favorable environments.

Table 3. Estimates of adaptability and stability generated by the model of Eberhart and Russell (1966) and AMMI1 for yield in 10 soybean cultivars grown in four locations and in three sowing season in Paraná.

\begin{tabular}{cllllll}
\hline \multirow{2}{*}{ Genotype } & \multicolumn{3}{c}{ Eberhart and Russell } & \multicolumn{2}{c}{ AMMI } \\
\cline { 2 - 6 } & Mean & $\beta 1$ & $\mathrm{~S}^{2} \mathrm{~d}$ & $\mathrm{R}^{2}(\%)$ & CP/Axis & IPCA \\
\hline SYN 1049 & $3,537.24$ & 1.05 & $299601.06^{* *}$ & 31.437 & 1 & 0.4318 \\
SYN 1152 & $3,779.52$ & 1.10 & $22723.23^{\text {ns }}$ & 71.052 & 2 & 0.2358 \\
SYN 1059 & $3,993.00$ & 0.83 & $-6790.81^{\text {ns }}$ & 70.336 & 3 & 0.1304 \\
SYN 3358 & $3,576.78$ & 0.72 & $5795.17^{\text {ns }}$ & 57.377 & 4 & 0.1108 \\
SYN 1163 & $3,928.26$ & 0.98 & $71178.53^{*}$ & 53684 & 5 & 0.0356 \\
SYN 1157 & $4,117.74$ & 1.08 & $114341.58^{* *}$ & 50.912 & 6 & 0.0228 \\
V-MAX & $3,859.26$ & 0.81 & $82094.58^{* *}$ & 42.214 & 7 & 0.0208 \\
FT - C. Mourão & $3,707.28$ & 0.88 & $86,156.85^{* *}$ & 45.477 & 8 & 0.0079 \\
BMX POTÊNCIA & $3,790.50$ & 0.92 & $885.92^{\text {ns }}$ & 71.065 & 9 & 0.0041 \\
SYN 9070 & $3,828.75$ & $1.61^{*}$ & $34,497.45^{\text {ns }}$ & 81.795 & 10 & \\
\hline
\end{tabular}

$(ß 1) *$ ** Significantly different from one, by the t-test, at 5 and $1 \%$ error of probability.

$\left(\mathrm{S}^{2} \mathrm{~d}\right) * * *$ Significantly different from one, by the $\mathrm{F}$ test, at 5 and $1 \%$ error of probability.

(ß1) Regression coefficient. $S^{2} d$, variance of deviation from the regression, $\mathrm{R}^{2}(\%)$, determination coefficient.

Soybean cultivars SYN 1049, SYN 1152, SYN 1059, SYN 3358, SYN 1163, SYN 1157, V-MAX, FT - C. Mourão, and BMX POTENCY showed the component $\beta 1=1$, indicating they are cultivars with wide adaptability to environmental conditions (Table 3). Genotypes characterized as having general or wide adaptability, respond satisfactorily to environmental improvements and may maintain their income when environmental conditions are adverse and/or less favorable (CRUZ et al., 2012).

Analysis of stability assessed by deviations from regression $\left(\mathrm{S}^{2} \mathrm{~d}\right)$ using the methodology described by Eberhart and Russell showed that soybean cultivars SYN 1152, SYN 1059, SYN 3358, BMX Potency, and, SYN 9070 did not deviate significantly, and are therefore, stable under these environmental conditions (Table 3). Cultivars showing predictability to the environment, either by changes in the number of hours of light, temperature, precipitation, and management, can identify changes and acclimatize to them faster, resulting in larger yields when subjected to different conditions. However, analysis of stability permits the recommendation of cultivars and does not consider their adaptation and/or average productivity. Stability is considered as the ability of genotypes to exhibit a steady performance, depending on variations in the environmental quality (CRUZ et al., 2012; RAMALHO et al., 2012).

Thus, the cultivars SYN 1152, SYN 1059, SYN 3358, BMX POTENCY, and SYN 9070 showed wide adaptability and stability to the 12 environmental conditions in which they were assessed by the Eberhart and Russell method. To overcome the effects of significant $\mathrm{G} \times \mathrm{E}$ interaction, procedures adopted to overcome and minimize the magnitude of the interaction include the recommendation of cultivars with wide adaptability and high phenotypic stability (BARROS et al., 2010b). 
The coefficient of determination (R2) described by Cruz et al. (1989) classifies values higher than $80 \%$ as strong, which are genotypes that act predictably to environmental changes. Among the 10 cultivars, SYN 9070 was notable, and generated a higher yield in the environments evaluated. However, the coefficient of determination values obtained for the cultivars, except for SYN 9070, were considerably lower, thus justifying the use of adaptability analysis methods and more refined stability for decomposition of the $\mathrm{G} \times \mathrm{E}$ interaction.

Through the analysis of AMMI, the main axis (IPCA1), corresponded to $43.18 \%$ of the variation for $\mathrm{SQ}_{\mathrm{G} \times \mathrm{E}}$ (Table 3). The proportion of variation observed for this component lies within the range of $36-45 \%$; this is similar to values previously reported in soybean by Maia et al. (2006) (39.85\%); Pereira and Costa (1998) (44.6\%), and Yokomizo et al. (2013) (44\%). Based on those results, it is possible to state that for grain yield, under the conditions evaluated, about half of the variation related to additive deviations of the main effects (genotypes and environments) can be captured by the first main component of interaction (DUARTE; VENCOVSKY, 1999). It is also important to note that very low proportions of $\mathrm{SQ}_{\mathrm{G} \times \mathrm{E}}$ indicate contamination of the array by unique interactions of unpredictable factors, depreciating the quality of their estimates $(\widehat{\mathrm{ga}})_{\mathrm{ij}}$. Thus, it can be inferred that, under such situations, traditional methods may provide inadequate yield predictions that are of inferior quality compared to those provided by the AMMI model (OLIVEIRA et al., 2003).

Regarding the other axes, the contribution of another IPCA2 component was considered significant, representing $23.58 \%$ of the variation of $\mathrm{SQ}_{\mathrm{G} \times \mathrm{E}}($ Table 3$)$. Thus, the first two components explain $66.76 \%$ of the $\mathrm{SQ}_{\mathrm{G} \times \mathrm{E}^{*}}$. The magnitude of variation captured by these two components can be considered as the "standard" level associated with the $\mathrm{G} \times \mathrm{E}$ interaction, to the set of data-model assessed. Thus, the other major components were excluded from the analysis because they were mainly composed of "noise" (SILVA; BENIN, 2012; YOKOMIZO et al., 2013.). The sum of the first two components is consistent with the findings of other studies on soybean with the AMMI biplot, where the first two components explained 61 to $88 \%$ of the $\mathrm{SQ}_{\mathrm{G} \times \mathrm{E}}$ and were significant (CAMPBELL; JONES, 2005; KAYA et al., 2006; TARAKANOVAS; SPRAINAITIS, 2005).

The soybean cultivars, or environments with points laying closer to the origin of the biplot chart coordinate system, are considered more stable (DUARTE; VENCOVSKY, 1999); therefore, in the AMMI1 (Figure 1) and AMM2 (Figure 1 b) graphs, most genotypes revealed considerable dispersion, indicating interaction with the environments (specific adaptations). In the AMM1 (IPCA1 vs. means) biplot, the most stable genotypes, which contributed less to the interaction, were captured by IPCA1 and were the cultivars SYN 1163, SYN 1157, SYN 9070, and SYN 1059 (VMAX). Therefore, these cultivars can be considered stable, due to their small contribution to the $\mathrm{G} \times \mathrm{E}$ interaction. Among those cultivars, SYN 1157, SYN 1059, and SYN 1163 can be considered as those with the best average yield due to their presence in the quadrants to the right of the biplot graph. Cultivars SYN 1059, SYN 1163, and V-MAX also have a tendency for specific adaptability to Assai-PR (A1 season 1), São Pedro do Ivaí-PR (A5 season 2), and Cornelius-PR (A7 season 1, A8 season 2). This statement can be verified by the proximity of graphical representations of cultivars with four environments in the upper right quadrant of Figure 1a. The SYN 1157 and SYN 9070 cultivars revealed adaptive specificity to the A2, A7, A8, A10, and A11 environments, which are Assai, season 2, Cornelius seasons 1 and 2, and South Marilândia season 1 (Figure 1a). 
Figure 1. (a) AMMI analysis biplot (productivity vs. IPCA1) (a) and (b) AMMI2 biplot (IPCA1 vs. IPCA2) of grain productivity of 10 soybean cultivars (G1-G10) SYN 1049 (G1), SYN 1152 (G2), SYN 1059 (G3), SYN 3358 (G4), SYN 1163 (G5), SYN 1157 (G6), V-MAX (G7), FT Campo Mourão (G8), BMX Potência (G9), and, SYN 9070 (G10) evaluated in 12 environments (A1-A12) [local Assaí-PR (A1 season 1, A2 season 2, A3 season 30)], [locality of São Pedro do Ivaí-PR (A4 season 1, A5 season 2, A6 season 3)], [Cornélio Procópio-PR (A7 season 1, A8 season 2, A9 season 3)], and [Marilândia do Sul-PR (A10 season 1, A11 season 2, A12 season 3)].

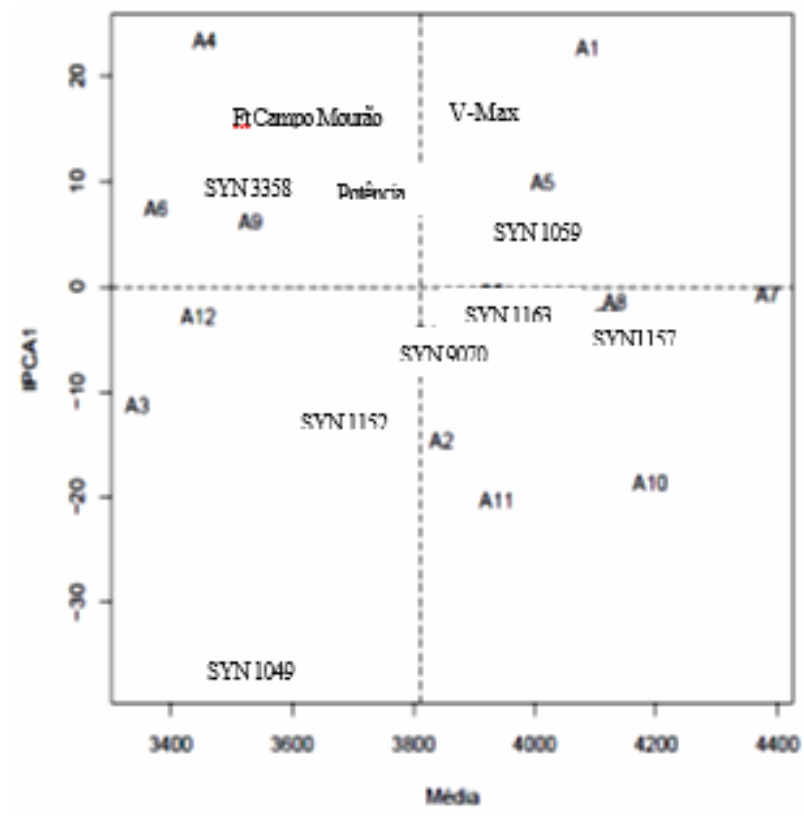

The AMMI2 biplot (Figure 1b) confirmed the genotypic behavior observed in the previous analysis; therefore, ICPA1 captured much of the standard $\mathrm{G} \times \mathrm{E}$ interaction of the character studied, but the second IPCA2 component was also significant. Thus, the information captured by the latter can correct possible distortions in the interpretation produced under a single dimension (SILVA; BENIN, 2012; YOKOMIZO et al., 2013). Moreover, stable behavior is thus confirmed along with the productive performance of the genotypes SYN 1163, SYN 1059, and V-MAX. Moreover, the cultivars SYN 9070 and SYN 1157, which were initially stable (IPCA vs. Medium) during the analysis of only one interaction axis, were found to contribute to the $\mathrm{G} \times \mathrm{E}$ interaction that was captured on the second main axis (IPCA2), which contradicts their productive stabilities, not being indicated to evaluate the phenotypic predictability of productivity only by ICPA1. According to Yokomizo et al. (2013), factors related to the $\mathrm{G} \times \mathrm{E}$

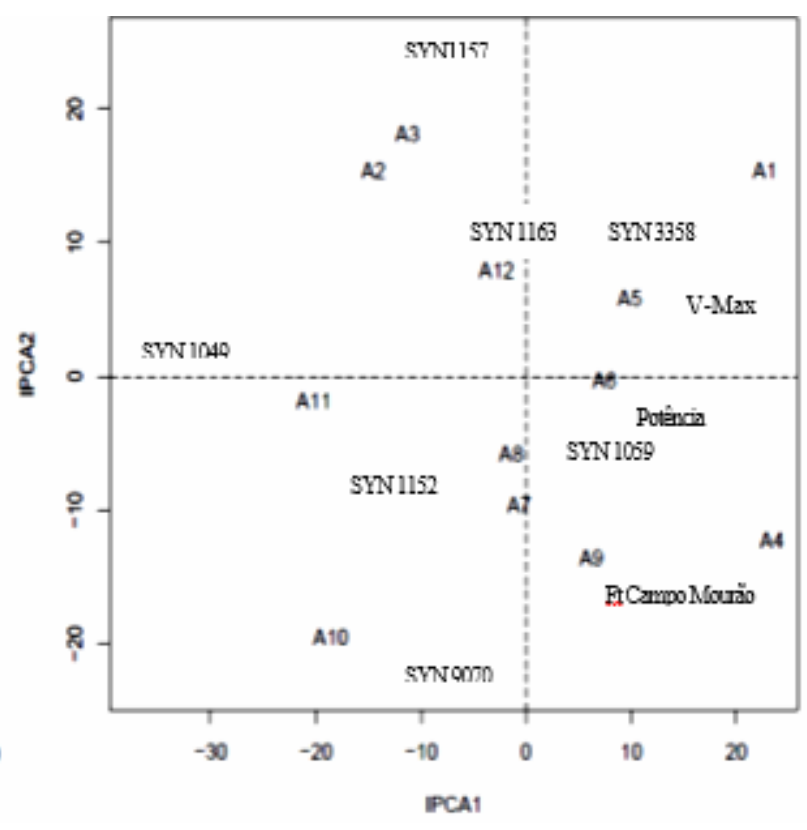

interaction ICPA1 and ICPA2 axes are independent; thus, there should be no loss of generality in cases involving more selected axes, where these factors cannot be disregarded in interpretations where significant effects are indicated. The refinement of the analysis using two axes can correct or refine the adaptive behavior of the cultivars, and BMX Potency, SYN 3358, and FT Campo Mourão have superior productivity performance, and high phenotypic stability. The cultivar that showed the highest indicators of phenotypic instability was SYN 1049, as determined through the biplot analysis (Figure 1a and 1b), and thus contributes more to the $\mathrm{G} \times \mathrm{E}$ interaction.

Analysis of the environments showed that these were more likely to contribute to the $\mathrm{G} \times \mathrm{E}$ interaction than the cultivars. This can be observed by the greater dispersion of the vectors associated with the environments in both biplots (Figure $1 \mathrm{a}$ and $1 \mathrm{~b}$ ). This behavior has been observed in other studies, and it is important to examine the 
positive effects of the interaction more efficiently (MARTINS et al., 2012; MEOTTI et al., 2012; YOKOMIZO et al., 2013). Regarding the influence of the environment to the interaction noted in the biplot analysis, it contrasts in the dispersion show that the three sowing dates in Assai (A1, A2, and A3) contributed to the $\mathrm{G} \times \mathrm{E}$ interaction; similarly, the three sowing seasons in São Pedro do Ivaí (A4, A5, and A6), Marilândia do Sul (A10, A11, and A12) were essential for the $G \times E$ interaction to reveal significance. These results suggest that the sowing season is directly related to the agronomic performance of the cultivars presented in this study, given the contrasts in the dispersion of the sowing dates shown in Figures 1a and 1b. As reported in the literature, losses of 30-70\% can occur (BRACCINI et al., 2004; RODRIGUES et al., 2008; STÜLP et al., 2009). Therefore, these findings confirm that cultivars have different yield performance gains according to the season of sowing. Significant losses indicate that the adoption of an appropriate seeding season is of the utmost importance to obtain a high grain yield (PEIXOTO et al., 2000; RIBEIRO et al., 2000).

The Eberhart and Russell (1966) and AMMI biplot models partially agree in terms of the phenotypic stability parameter. Given the advantages of AMMI models over the traditional models, decision making and inferences based on the AMMI method become more accurate by finely adjusting the effects of the $\mathrm{SQ}_{\mathrm{G} \times \mathrm{E}}$.

\section{Conclusions}

The Eberhart and Russell model is partially consistent with the phenotypic stability parameter of the cultivars studied here.

The Eberhart and Russell analysis showed that cultivar SYN 9070 is responsive to environmental improvement, has high predictability, is stable under 12 environmental conditions, and generates income that is higher than the overall average of the cultivars.
On the other hand, cultivars SYN 1059, SYN 1163, and VMAX stand out for their considerably higher productivity performance and the broad productive adaptation of local and sowing dates.

Based on the AMMI analysis, the cultivar SYN 1163 shows commercial promise among other cultivars in terms of high performance grain yield, adaptation to regions and sowing times, and by the predictability of the response.

\section{References}

BARBOSA, M. C.; LUCCA, A. de; SCAPIM, C. A.; ALBRECHT, L. P.; PICCININ, G. G.; ZUCARELI, C. Desempenho agronômico e componentes da produção de cultivares de soja em duas épocas de semeadura no arenito caiuá. Semina: Ciências Agrárias, Londrina, v. 34, n. 3, p. 945-960, 2013.

BARROS, H. B.; SEDIYAMA, T.; CRUZ, C. D.; TEIXEIRA, R. de C.; REIS, M. S. Análise de adaptabilidade e estabilidade em soja (Glycine max L.) em Mato Grosso. Ambiência, Guarapuava, v. 6, n. 1, p. 75-88, 2010a.

BARROS, H. B.; SEDIYAMA, T.; TEXEIRA, R. C.; FIDELIS, R. R.; CRUZ, C.D.; REIS, M. S. Adaptabilidade e estabilidade de genótipos de soja avaliados no estado do Mato Grosso. Revista Ceres, Viçosa, MG, v. 57, n. 3, p. 359-366, 2010 b.

BRACCINI, A. de L. e; MOTTA, I. de S.; SCAPIM, C. A.; BRACCINI, M. do C. L.; ÁVILA, M. R.; MESCHEDE, D. K. Características agronômicas e rendimento de sementes de soja na semeadura realizada no período de safrinha. Bragantia, Campinas, v. 63, n. 1, p. 81-92, 2004.

BRANQUINHO, R. G.; DUARTE, J. B.; SOUZA, P. I. M. de; SILVA NETO, S. P. da; PACHECO, R. M. Estratificação ambiental e otimização de rede de ensaios de genótipos de soja no Cerrado. Pesquisa Agropecuária Brasileira, Brasília, v. 49, n. 10, p. 783-795, 2014.

CAMARGO-BUITRAGO, I.; INTIRE, E. Q-Mc; GÓRDON-MENDOZA, R. Identificación de megaambientes para potenciar el uso de genotipos superiores de arroz en Panamá. Pesquisa Agropecuária Brasileira, Brasília, v. 46, n. 9, p. 1061-1069, 2011.

CAMPBELL, B. T.; JONES, M. A. Assessment of genotype $\mathrm{x}$ environment interactions for yield and fiber quality in cotton performance trials. Euphytica, Wageningen, v. 144, n. 1, p. 69-78, 2005. 
CARVALHO, A. D. F.; SILVA, G. O. da; PEREIRA, R. B.; PINHEIRO, J. B. Análise de fatores e regressão bissegmentada no estudo da adaptabilidade e estabilidade de cenoura. Revista Ceres, Viçosa, MG, v. 61, n. 6, p. 932-940, 2014.

CORNELIUS, P. L.; SEYEDSADR, M.; CROSSA, J. Using the shifted multiplicative model to search for separability in crop cultivar trials. Theoretical and Applied Genetics, Berlin, v. 84, n. 1-2, p. 161-172, 1992.

CRUZ, C. D. GENES - a software package for analysis in experimental statistics and quantitative genetics. Acta Scientiarum. Agronomy, Maringá, v. 35, n. 3, p. 271-276, 2013.

CRUZ, C. D.; CARNEIRO, P. C. S. Modelos biométricos aplicados ao melhoramento genético. Viçosa, MG: UFV, 2003. v. 2, 585 p.

CRUZ, C. D.; REGAZZI, A. J.; CARNEIRO, P. C. S. Modelos biométricos aplicados ao melhoramento genético. 4. ed. Viçosa, MG: UFV, 2012. 514 p.

CRUZ, C. D.; TORRES, R. A. de; VENCOVSKY, R. Alternative approach to the stability analysis proposed by Silva and Barreto. Revista Brasileira de Genética, Ribeirão Preto, v. 12, n. 13, p. 567-582, 1989.

DUARTE, J. B.; VENCOVSKY, R. Interação genótipos $x$ ambientes: uma introdução à análise AMMI. Ribeirão Preto: Sociedade Brasileira de Genética, 1999. 60 p.

EBERHART, S. A.; RUSSELL, W.A. Stability parameters for comparing varieties. Crop Science, Madison, v. 6, n. 1, p. 36-40, 1966.

GAUCH, H. G.; ZOBEL, R. W. AMMI analysis of yield trials. In: KANG, M. S.; GAUCH, H. G. (Ed.). Genotype-by-environment interaction. New York: CRC Press, 1996. 416 p.

KAYA, Y.; AKÇURA, M.; TANER, S. GGE-biplot analysis of multi-environment yield trials in bread wheat. Turkish Journal of Agriculture and Forestry, Ankara, v. 30, p. 325-337, 2006.

MAIA, M. C. C.; VELLO, N. A.; ROCHA, M. de M.; PINHEIRO, J. B.; SILVA JÚNIOR, N. F. da. Adaptabilidade e estabilidade de linhagens experimentais de soja selecionadas para caracteres agronômicos através de método uni-multivariado. Bragantia, Campinas, v. 65, n. 2, p. 215-226, 2006.

MARTINS, J. A. S.; JULIATTI, F. C. Adaptability and stability of soybean advanced lines of semi early cycle for rust resistance. Crop Breeding and Applied Biotechology, v. 12, n. 1, p. 43-51, 2012.

MEOTTI, G. V.; BENIN, G.; SILVA, R. R.; BECHE, E.; MUNARO, L. B. Épocas de semeadura e desempenho agronômico de cultivares de soja. Pesquisa Agropecuária Brasileira, Brasília, v. 47, n. 1, p. 14-21, 2012.

MIRANDA, G. V.; VIEIRA, C.; CRUZ, C. D.; ANDRADE ARAÚJO, G. A. de. Comparação de métodos de avaliação da adaptabilidade e da estabilidade de cultivares de feijoeiro. Acta Scientiarum. Agronomy, Maringá, v. 20, n. 3, p. 249-255, 2008.

OLIVEIRA, A. B. de; DUARTE, J. B.; PINHEIRO, J. B. Emprego da análise AMMI na avaliação da estabilidade produtiva em soja. Pesquisa Agropecuária Brasileira, Brasília, v. 38, n. 3, p. 357-364, 2003.

PACHECO, R. M.; DUARTE, J. B.; SOUZA, P. I. M. de; SILVA, S. A. da; NUNES JUNIOR, J. Key locations for soybean genotype assessment in Central Brazil. Pesquisa Agropecuária Brasileira, Brasília, v. 44, n. 5, p. 478-486, 2009.

PEIXOTO, C. P.; CÂMARA, G. M. de S.; MARTINS, M. C.; MARCHIORI, L. F. S.; GUERZONI, R. A.; MATTIAZZI, P. Épocas de semeadura e densidade de plantas de soja: I. componentes da produção e rendimento de grãos. Scientia Agrícola, Piracicaba, v. 57, n. 1, p. 4761, 2000.

PEREIRA, A. S.; COSTA, D. M. Análise de estabilidade de produção de genótipos de batata no Rio Grande do Sul. Pesquisa Agropecuária Brasileira, Brasília, v. 33, n. 4, p. 405-409, 1998.

PIEPHO, H. P. Robustness of statistical test for multiplicative terms in the additive main effects and multiplicative interaction model for cultivar trial. Theoretical and Applied Genetics, Amsterdam, v. 90, n. 3, p. 438-443, 1995.

RAMALHO, M. A. P.; ABREU, A. F. B.; SANTOS, J. B.; NUNES, J. A. R. Aplicações da genética quantitativa no melhoramento de plantas autógamas. Lavras: Ed. UFLA, 2012. 522 p.

RIBEIRO, P. H. E.; RAMALHO, M. A. P.; FERREIRA, D. F. Adaptabilidade e estabilidade de genótipos de milho em diferentes condições ambientais. Pesquisa Agropecuária Brasileira, Brasília, v. 35, n. 11, p. 2213$2222,2000$.

RODRIGUES, O.; TEIXEIRA, M. C. C.; COSTENARO, E. R.; AVOZANI, A. Rendimento de grãos de soja em semeadura tardia. Passo Fundo: EMBRAPA Trigo, 2008. 26 p. (EMBRAPA Trigo. Boletim de Pesquisa e Desenvolvimento Online, 66).

SCHMILDT, E. R.; NASCIMENTO, A. L.; CRUZ, C. D.; OLIVEIRA, J. A. R. Avaliação de metodologias de adaptabilidade e estabilidade de cultivares milho. Acta Scientiarum. Agronomy, Maringá, v. 33, n. 1, p. 51-58, 2011. 
SILVA, R. R.; BENIN, G. Análises Biplot: conceitos, interpretações e aplicações. Ciência Rural, Santa Maria, v. 42, n. 8, p. 1404-1412, 2012.

STÜLP, M.; BRACCINI, A. L. de; ALBRECHT, L. P.; ÁVILA, M. R.; SCAPIM, C. A.; SCHUSTER, I. Desempenho agronômico de três cultivares de soja em diferentes épocas de semeadura em duas safras. Ciência e Agrotecnologia, Lavras, v. 33, n. 5, p. 1240-1248, 2009.

SUBEDI, K. D.; MA, B.-L.; XUE, A. G. Planting date and nitrogen effects on grain yield and protein content of spring wheat. Crop Science, Madison, v. 47, n. 1, p. 36-47, 2007.
TARAKANOVAS, P.; SPRAINAITIS, A. Main additive effect and multiplicative interaction analysis of white clover genetic resources. Biologija, Vilnius, n. 4, p. 3842, 2005.

YOKOMIZO, G. K. I.; DUARTE, J. B.; VELLO, N. A.; UNFRIED, J. R. Análise AMMI da produtividade de grãos em linhagens de soja selecionadas para resistência à ferrugem asiática. Pesquisa Agropecuária Brasileira, Brasília, v. 48, n. 10, p. 1372-1380, 2013. 